\title{
Effects of a nanoemulsion with Copaifera officinalis oleoresin against monogenean parasites of Colossoma macropomum: A Neotropical Serrasalmidae
}

\author{
D S S Valentim ${ }^{1}$ | J L Duarte ${ }^{2}$ | A E M F M Oliveira ${ }^{2}$ | R A S Cruz ${ }^{2}$ | \\ J C T Carvalho ${ }^{1,3} \mid$ C Solans $^{4} \mid$ C P Fernandes ${ }^{1,2} \mid$ M Tavares-Dias ${ }^{1,5}$
}

${ }^{1}$ Programa de Pós-Graduação em Biodiversidade Tropical (PPGBIO), Universidade Federal do Amapá, Macapá, Brazil

${ }^{2}$ Laboratorio Nanobiotecnologia Farmacêutica, Universidade Federal do Amapá, Macapá, Brazil

${ }^{3}$ Laboratório de Pesquisas de Drogas, Universidade Federal do Amapá, Macapá, Brazil

${ }^{4}$ Instituto Avançado de Química da Catatonia (IQAC-CSIC), Barcelona, Spain

${ }^{5}$ Embrapa Amapá, Macapá, Brazil

\section{Correspondence}

Marcos Tavares-Dias, Embrapa Amapá,

Macapá, Brazil.

Email: marcos.tavares@embrapa.br

Funding information

Fundação de Amparo a Pesquisa do Amapá, Grant/Award Number: 250.203.035/2013;

Conselho Nacional de Desenvolvimento Científico e Tecnológico, Grant/Award Number: 303013/2015-0; Embrapa

\begin{abstract}
Monogeneans are ectoparasites that may cause losses in production and productivity in the aquaculture of Colossoma macropomum. Chemotherapeutics used in aquaculture usually have major adverse effects on fish; hence, the use of essential oils has been considered advantageous, but these are not soluble in water. Thus, the use of nanostructures to enhance water solubility of compounds and improve bioactivity may be very promising. This study investigated the antiparasitic activity of nanoemulsion prepared with Copaifera officinalis oleoresin (50, 100, 150, 200 and $300 \mathrm{mg} / \mathrm{L}$ ), against monogenean parasites from the gills of $C$. macropomum. The particle size distribution and zeta potential suggested that a potentially kinetic stable system was generated. The nanoemulsion from $C$. officinalis oleoresin achieved high efficacy (100\%) at low concentrations (200 and $300 \mathrm{mg} / \mathrm{L}$ ) after $15 \mathrm{~min}$ of exposure. This was the first time that a nanoemulsion was generated from $C$. officinalis oleoresin using a solvent-free, non-heating and low-energy method. Moreover, this was the first time that an antiparasitic against monogeneans on fish gills, based on nanoemulsion of $C$. officinalis oleoresin, was tested.
\end{abstract}

KEYWORDS

efficacy, freshwater fish, nanoemulsion, parasites, tambaqui

\section{1 | INTRODUCTION}

Colossoma macropomum Cuvier 1816 (tambaqui) is a fish of the family Serrasalmidae that can reach more than one metre in length and up to $30 \mathrm{~kg}$ in its natural environment. It is economically important in the Amazon region, and there is high demand for it in Brazil, such that around 140,000 tons were produced through aquaculture in 2015 (IBGE, 2016; Valladão, Gallani, \& Pilarski, 2016). However, its fish stocks are under high fishery pressure, and it has become extinct in some localities in Amazon (Araújo-Lima \& Goulding, 1998; Benetton \& Malta, 1999; Godoi, Engracia, Lizama, \& Takemoto, 2012; Gomes et al., 2006). Intensive fish farming of tambaqui presents a critical problem of high levels of infections by ectoparasites such as the monogeneans Anacanthorus spathulatus, Notozothecium janauachensis and Mymarothecium boegeri, which can cause economic loss to aquaculture (Tavares-Dias \& Martins, 2017).

Continuous monitoring is required for diagnosing and controlling parasitic infections within tambaqui aquaculture. The main substances that have been used for treatment and parasite control, even they have not been satisfactorily effective, are chemical products that are highly toxic to fish, humans and environment (Hashimoto et al., 2016; Soares et al., 2016). Thus, phytotherapeutic agents with bioactive properties, and their derivatives, have been assayed in vitro and in vivo, with the aim of finding better strategies for fish ectoparasites control in farmed fish (Boijink, Miranda, Chagas, Dairiki, \& Inoue, 2015; Costa et al., 2017; Pandey, 2014; Soares et al., 2016; Zhang et al., 2014). Phytotherapeutic agents have shown high in vitro efficacy against monogeneans of tambaqui (Boijink et al., 2015; Soares 
et al., 2016). However, a low in vivo efficacy has been observed, due to low tolerance of fish to toxic concentrations of some essential oils (Hashimoto et al., 2016; Soares et al., 2016) and other problems.

Several bioactive natural products have also a low water solubility because of their oily characteristics. This is considered to be a major disadvantage for aquaculture fish, as it is difficult to make these compounds available in water. Nanoemulsions offer several benefits including sustained release, increased rate of absorption and therapeutic efficacy, reducing the toxicity and concentration of drugs (Bajerski et al., 2016; Valentim et al., 2018). Aqueous nanodispersions, including nanoemulsions, are kinetically stable systems consisting of fine droplets or particles that are dispersed into an aqueous external phase. The mean droplet size of nanoemulsions is often within the range of 20 $200 \mathrm{~nm}$, although this criterion may vary according to different authors (Bajerski et al., 2016; Solans, Izquierdo, Nolla, \& Azemar, 2005; Solè, Solans, Maestro, González, \& Gutiérrez, 2012; Thomas et al., 2013; Valentim et al., 2018). The main advantages of nanoemulsions are system stability, potential improvement of bioavailability, enhanced water solubility (oil-in-water nanoemulsion), and other properties are due precisely to the nanosized particles (Ostertag, Weiss, \& McClements, 2012; Rodrigues et al., 2014). The intrinsic low solubility or immiscibility of internal phase components makes this type of novel delivery system very promising for controlling fish diseases (Rodrigues et al., 2014; Thomas et al., 2013). Moreover, nanosize potentially increases the bioactivity of the compounds used (Irache et al., 2011), such that this is very promising for effective treatment, even at lower concentrations than usual for antiparasitic products. For these reasons, nanoemulsions have been tested as an alternative to increase the stability, efficacy and solubility of essential oils (Valentim et al., 2018). This nanotechnology technique may be very promising in treatment of parasitic infections for C. macropomum (Soares et al., 2016; Valentim et al., 2018), for example, in the use of Copaifera officinalis oleoresin.

Copaifera officinalis (Caesalpinioideae) belongs to the family Fabaceae, and it is commonly known as copaiba. Copaifera spp. are Amazon plants known for their antibacterial, anthelmintic and antiprotozoal properties (Costa et al., 2017; Rodrigues et al., 2014; Simões et al., 2016). It is a mixture of several substances, among which the sesquiterpene $\beta$-caryophyllene is the main constituent (Lima et al., 2011; Veiga-Junior, Zunino, Patitucci, Pinto, \& Calixto, 2006). However, to the best of our knowledge, no studies had previously been conducted to evaluate the antiparasitic activity of nanoemulsions prepared with $C$. officinalis against fish parasites. The aim of this study was to perform a nanoemulsion of $C$. officinalis oleoresin and investigate the effect in vitro of this nanoproduct against monogeneans on the gills of $C$. macropomum.

\section{2 | MATERIALS AND METHODS}

\section{1 | Chemicals}

Copaifera officinalis oleoresin was obtained from Amazon Ervas (Brazil, batch number 009105845), and polysorbate 80 was obtained from Praid (SP, Brazil).

\subsubsection{Gas chromatography analysis of $C$. officinalis oleoresin}

The chemical analysis on the oleoresin was performed on a GCMSQP5000 gas chromatography (Shimadzu, Japan) equipped with a mass spectrometer, using electron ionization, with the following experimental conditions: injector temperature, $200^{\circ} \mathrm{C}$; detector temperature, $250^{\circ} \mathrm{C}$; carrier gas, helium; flow rate, 1 per $\mathrm{ml}$ per min; and split injection with split ratio 1:40. The oven temperature was programmed starting from $50^{\circ} \mathrm{C}$ (isothermal for $10 \mathrm{~min}$ ), with an increase of $2^{\circ} \mathrm{C} / \mathrm{min}$ to $200^{\circ} \mathrm{C}$ and then an increase of $10^{\circ} \mathrm{C} / \mathrm{min}$ to $290^{\circ} \mathrm{C}$ (isothermal for $10 \mathrm{~min}$ ). The RTx5-5MS column parameters were as follows: i.d. $=0.25 \mathrm{~mm}$; length $30 \mathrm{~m}$; and film thickness $=0.25 \mu \mathrm{m}$. The mass spectrometry conditions were as follows: ionization voltage, $70 \mathrm{eV}$; scan rate, $1 \mathrm{scan} /$ $\mathrm{s}$; and mass range, $\mathrm{m} / \mathrm{z}$ 50-600.

\subsection{Copaifera officinalis oleoresin nanoemulsion}

The oil-in-water nanoemulsion containing $C$. officinalis oleoresin was prepared by means of a low-energy method. The oily phase, constituted by a non-ionic surfactant (polysorbate 80 ) and C. officinalis oleoresin, was vigorously mixed until a clear transparent homogeneous phase was observed. Then water was added dropwise under continuous homogenization using a vortex stirrer (Warmnest, lonlab, Brazil) for approximately $5 \mathrm{~min}$, such that the final concentration of oleoresin was $5,000 \mathrm{ppm}$. The oil-to-surfactant ratio was $1: 1$, and the final mass of the nanoemulsion was $10 \mathrm{~g}$. Dynamic light scattering (DLS) analysis was carried out on the particle size distribution using a Zetasizer Nano ZS (Malvern, UK) equipped with a $10 \mathrm{~mW}$ "red" laser $(\lambda=632.8 \mathrm{~nm}$ ), and samples were measured at a $90^{\circ}$ scatter detection angle, for size measurements. Zeta potential measurements were also performed using this equipment. The nanoemulsion was diluted in deionized water (1:25), and the results (droplet size and polydispersity index) were expressed as mean \pm standard deviation.

\subsection{Fish and acclimation}

Fingerlings of $C$. macropomum $(25.0 \pm 6.0 \mathrm{~g})$ were obtained from commercial fish farm in Macapá, state of Amapá, Brazil. The fish were acclimated in 500-L water tanks for 7 days at the Aquaculture and Fishery Laboratory of Embrapa Amapá (Macapá, Brazil). They were fed with fish ration containing $32 \%$ crude protein, and the tanks were kept under constant water recirculation with temperature of $30.2 \pm 0.1^{\circ} \mathrm{C}$, dissolved oxygen $5.6 \pm 0.2 \mathrm{mg} / \mathrm{L}, \mathrm{pH} 5.4 \pm 0.2$, total ammonium $0.5 \pm 0.2 \mathrm{mg} / \mathrm{L}$, alkalinity $10.0 \pm 0 \mathrm{mg} / \mathrm{L}$ and hardness $10.0 \pm 0 \mathrm{mg} / \mathrm{L}$. The organic matter that accumulated at the bottoms of the tanks was removed once a day.

\subsection{In vitro assay with monogeneans of C. macropomum}

Gills of C. macropomum $(47.5 \pm 14.7 \mathrm{~g}$ and $13.4 \pm 2.1 \mathrm{~cm})$ that were naturally infected by species of monogeneans were removed 
and placed individually in Petri dishes, where they were immersed in solutions of different nanoemulsions of $C$. officinalis oil. In this trial, in vitro gill arches containing monogeneans (A. spathulatus, $N$. janauachensis and My. boegeri) were exposed to six different concentrations of nanoemulsions with $C$. officinalis oleoresin $(0,50,100$, 150, 200 and $300 \mathrm{mg} / \mathrm{L}$ ). The control groups were set up, using only the water from the cultivation tanks. All the experiments, in each concentration, were performed in triplicates. All the in vitro assays were performed at the temperature of the environment $\left(23^{\circ} \mathrm{C}\right)$. For the analysis under a stereomicroscope, cold-light illumination was used, and fields of view containing 18 monogeneans were selected for each repetition. After the gill arches had been immersed in different concentrations of nanoemulsions of $C$. officinalis oleoresin, these were viewed every $5 \mathrm{~min}$ to quantify the numbers of live and dead monogeneans. Parasites were considered to be dead if they detached from the tissue or, while still attached, had totally lost their mobility (Soares et al., 2016). Following this, the efficacy of each treatment was calculated using formula described by Zhang et al. (2014): $A E=[B-T] \times 100 \% / B$, where $A E$ is nanoemulsion efficacy, $B$ is the mean number of surviving monogeneans in the control group and $\mathrm{T}$ is the mean number of surviving monogeneans in the treatment group. The monogeneans were collected, fixed in formalin (5\%) during $2 \mathrm{hr}$ and prepared to analyse the internal morphology using Hoyer medium to study of the sclerotized structures. Some monogeneans were also stained with Masson trichrome (Eiras, Takemoto, \& Pavanelli, 2006). The identification of the parasites was performed in accordance with Thatcher (2006).

\section{3 | RESULTS}

\section{1 | Gas chromatograph analysis}

The gas chromatograph analysis revealed the presence of several substances in the $C$. officinalis oleoresin (Figure 1). The mass spectra were concordant with the sesquiterpenes in the NIST library. High abundance of peaks was observed at a retention time (Rt) of $44.715 \mathrm{~min}$. Analysis on the mass spectra (Figure 2) and comparison with the NIST library and with data in the literature (Lucca et al., 2015) revealed a fragmentation pattern in accordance with $\beta$-caryophyllene.

\subsection{Copaifera officinalis oleoresin nanoemulsion}

The nanoemulsion prepared using $C$. officinalis oleoresin presented a homogeneous translucent appearance with bluish reflections (Figure 3a). A mixture of water, polysorbate 80 and C. officinalis oleoresin at the same ratios as was used in the nanoemulsion preparation was not able to induce formation of a nanoemulsion, such that a heterogeneous appearance was observed immediately after homogenization of the three components (Figure 3b). The droplet size distribution of the $C$. officinalis nanoemulsion revealed a mean droplet size of $161.2 \pm 0.808 \mathrm{~nm}$ and polydispersity index of $0.340 \pm 0.007$, while the zeta potential was $-22.1 \pm 0.764 \mathrm{mV}$. Analysis of these parameters after 7 days of storage (Figure 4) under controlled temperature $\left(25.5 \pm 2.0^{\circ} \mathrm{C}\right)$ showed that slight decreases in mean droplet size $(132.4 \pm 1.2 \mathrm{~nm})$ and polydispersity index $(0.297 \pm 0.006)$ and a slight increase in zeta potential $(-21.3 \pm 0.643 \mathrm{mV})$ had occurred. No alteration to the macroscopic appearance of the nanoemulsion was observed after this period.

\subsection{Antiparasitic efficacy of the in vitro assay}

The in vitro assay revealed that the nanoemulsion prepared with C. officinalis oleoresin induced $100 \%$ antiparasitic activity against the monogeneans A. spathulatus, N. janauachensis and M. boegeri on the gills of C. macropomum. This level of mortality was reached after $15 \mathrm{~min}$ of exposure at $200 \mathrm{mg} / \mathrm{L}$, while the same efficacy was reached after $90 \mathrm{~min}$ of exposure at $50 \mathrm{mg} / \mathrm{L}$ with nanoemulsion of

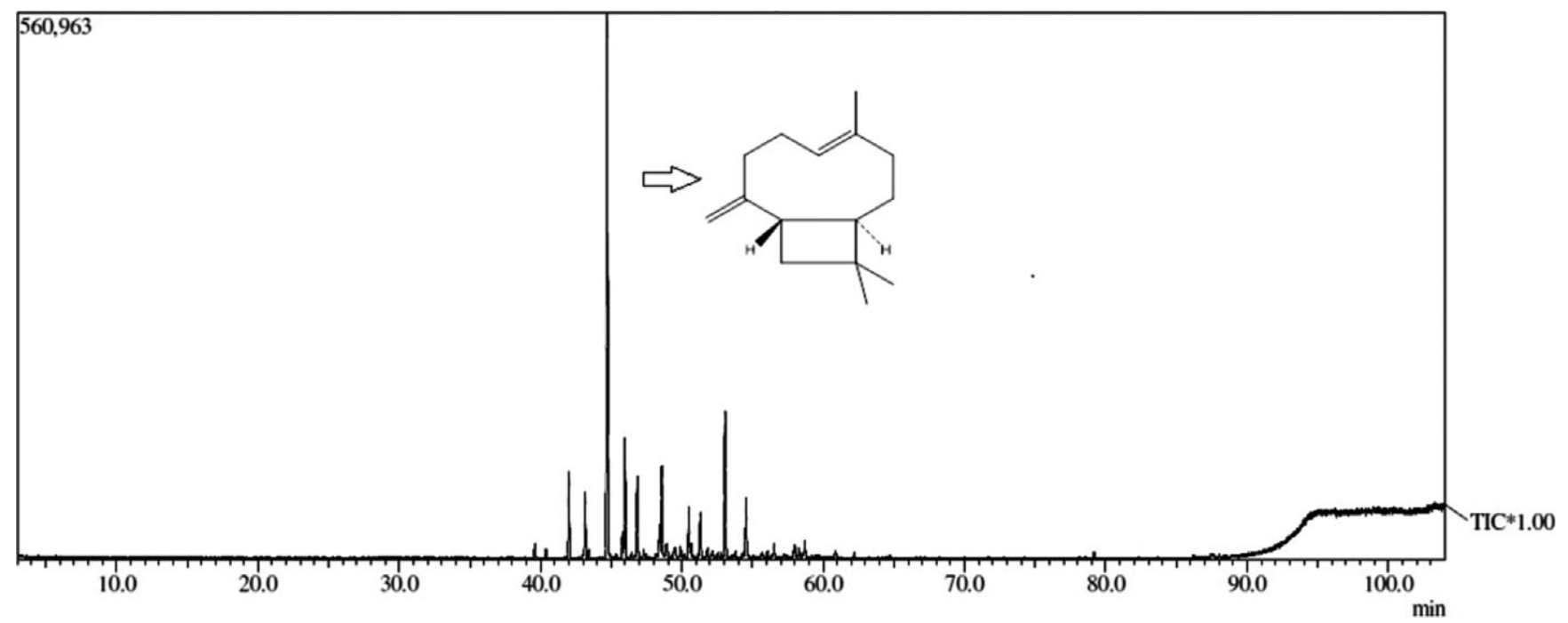

FIGURE 1 Total ion chromatogram of Copaifera officinalis oleoresin. High abundance of peaks at Rt $=44.715$ min is related to the sesquiterpene $\beta$-caryophyllene 


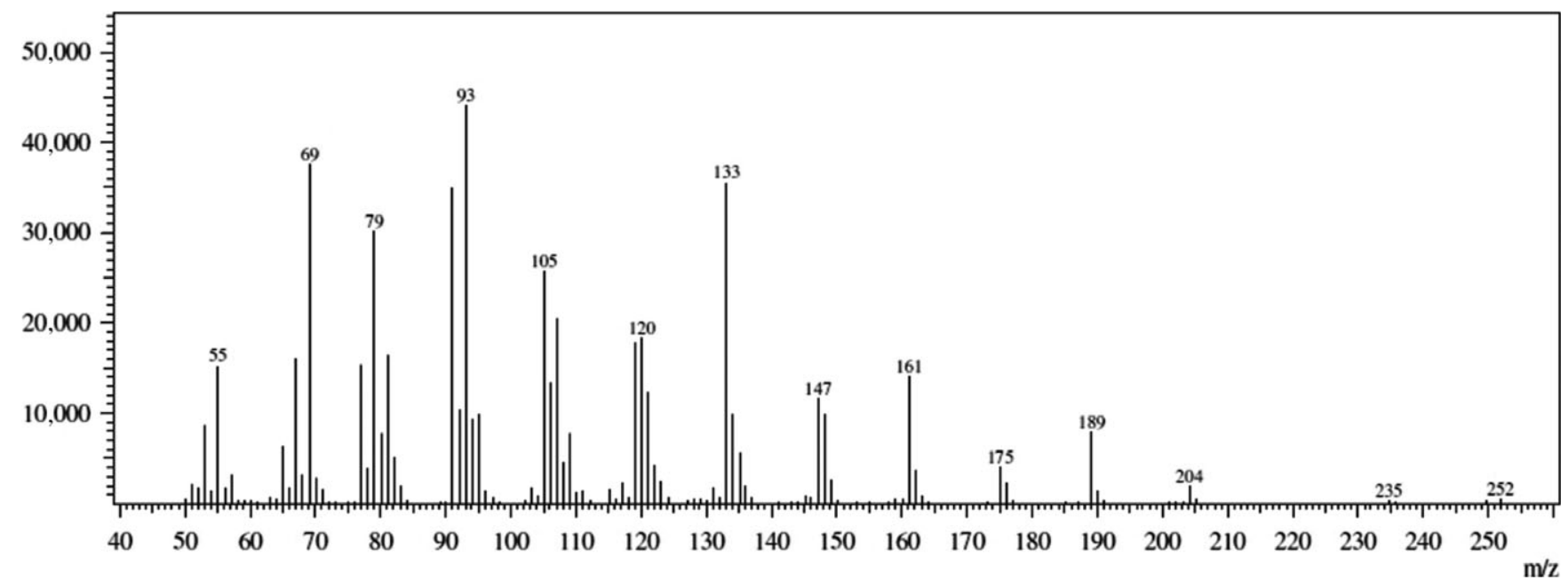

FIGURE 2 Mass spectra showing the fragmentation pattern of the sesquiterpene $\beta$-caryophyllene

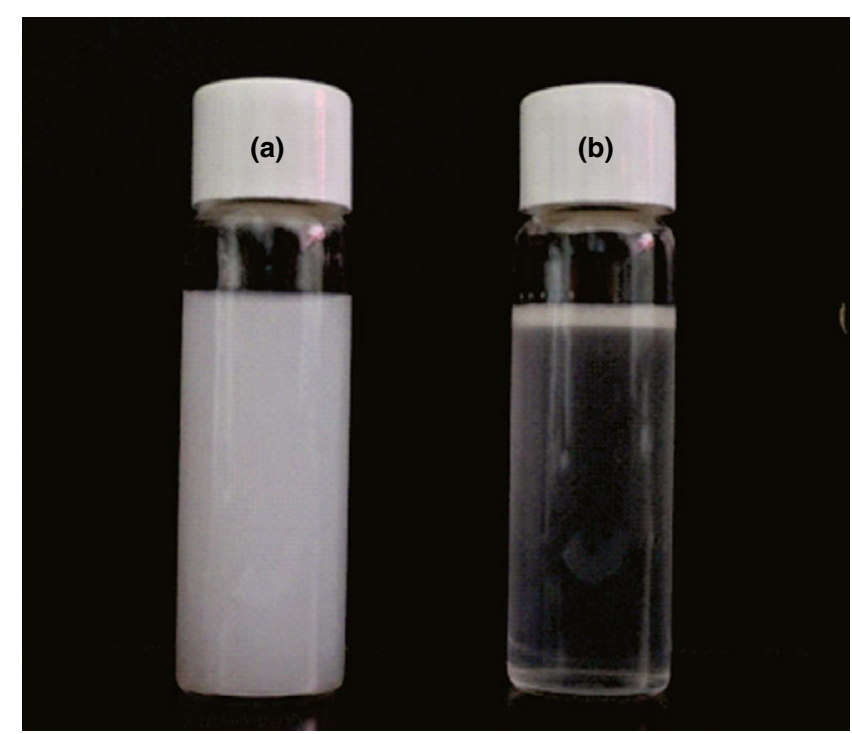

FIGURE 3 Photograph of glass vials containing (a) nanoemulsion prepared with Copaifera officinalis oleoresin $(5,000 \mathrm{ppm})$, polysorbate $80(5,000 \mathrm{ppm})$ and water; and (b) mixture of Co. officinalis oleoresin $(5,000 \mathrm{ppm})$ and polysorbate $80(5,000 \mathrm{ppm})$

C. officinalis oleoresin. In the control group, using only water of cultivation tanks, mortality of parasites began after $70 \mathrm{~min}$ of exposure and total immobilization of the monogeneans was observed after $7 \mathrm{hr}$ of exposure to the nanoemulsion from $\mathrm{C}$. officinalis oleoresin (Table 1 and Figure 5).

\section{DISCUSSION}

We prepared a nanoemulsion with $C$. officinalis oleoresin for the first time using a solvent-free, non-heating and low-energy method. An oleoresin nanoemulsion from $C$. multijuga had previously been successfully achieved, but it was produced using volatile organic solvents, through a spontaneous nanoemulsifying method (Dias et al., 2014). A high-pressure homogenizer has also been used for the preparation of C. multijuga oleoresin nanoemulsions (Dias et al., 2012, 2014; Lucca et al., 2015). Vaucher et al. (2015) also used this high-energy method for preparing a nanoemulsion from $C$. officinalis oleoresin. Eco-friendly processes for nanoemulsion preparation with less harm to fish, humans and the environment are very desirable. Methods that are able to generate nanostructures without using high-energy equipment should also be encouraged.

Our results suggest that it is possible to obtain $C$. officinalis nanoemulsions using a simple approach. Self-emulsification through dilution of microemulsions or cubic liquid crystal (Solè, Solans, Maestro, González, \& Gutiérrez, 2012) is considered to be possible mechanisms for nanoemulsion formation. Moreover, phase inversion at constant temperature (phase inversion composition) caused by changes to the spontaneous curvature of the surfactant from negative to positive, passing through zero curvature (e.g., bicontinuous microemulsion or lamellar liquid crystal) seems to have developed an important role in nanoemulsion formation through low-energy methods that do not involve heating (Solè, Solans, Maestro, González, \& Gutiérrez, 2012). However, most of the studies that aimed to investigate nanoemulsification mechanisms were carried out using synthetic and/or pure lipophilic components that constituted the internal phase. Thus, considering the complexity of natural oil such as $C$. officinalis oleoresin, deeper investigation regarding these processes needs to be undertaken.

The droplet size distribution of the nanoemulsions prepared from C. multijuga oleoresin revealed mean diameters in the range of 160 $300 \mathrm{~nm}$ (Dias et al., 2014). Our results showed that fine droplets could be successfully generated through a non-heating and lowenergy method, rather than through high-pressure homogenization and/or use of organic solvents.

The polydispersity index is a parameter associated with homogeneity of particle populations and results. The desirable values may be within the range from 0 (monodispersed) to 0.500 (relatively 


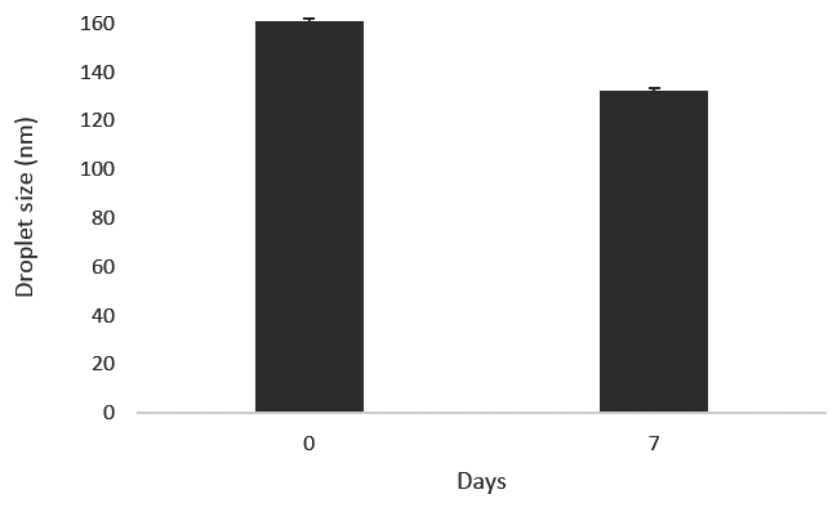

0.5

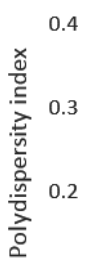

0.1

0

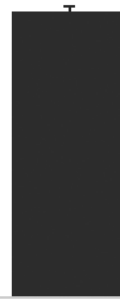

0

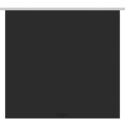

0

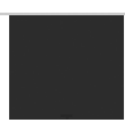

Days

FIGURE 4 Particle size distribution (droplet size and polydispersity index) and zeta potential of the nanoemulsion immediately after preparation (day 0) and after 7 days of storage (day 7) of the Copaifera officinalis oleoresin emulsion

broad distribution) (Cheong et al., 2008), while acceptable polydispersity index values are below 0.700 (Leong et al., 2011).

Zeta potential is an important parameter relating to the surface potential of the droplets, and high values (in modules) are associated with kinetically stable systems (Heurtault, Saulnier, Pech, Proust, \& Benoit, 2003). A previous study conducted using a nanoemulsion prepared from copaiba oleoresin from C. multijuga showed zeta potential of around $-23 \mathrm{mV}$ (Dias et al., 2012). This was close to the values achieved in this study.

$\beta$-caryophyllene is the main constituent of Copaifera spp. oleoresin (Cascon \& Gilbert, 2000; Simões et al., 2016). This sesquiterpene is a chemical marker for Copaifera species, and it is responsible for several forms of biological activity of the oleoresin of these plants (Lima et al., 2011; Tappin et al., 2004). This compound of

Copaifera spp. presents antimicrobial, anti-inflammatory, anthelmintic and antiprotozoal activities (Costa et al., 2017; Rodrigues et al., 2014; Simões et al., 2016). Preparation of nanoemulsions has proven to be a good strategy for avoiding volatile loss, including of this bioactive compound from Copaifera spp. oleoresin (Dias et al., 2014). The oleoresin from Copaifera duckei was heated prior to emulsification, as a means for generating oil-in-water nanoemulsions (Rodrigues et al., 2014). However, it is worth mentioning that some loss of volatiles may occur on this step. Thus, our study provides an alternative method for preparation of nanoemulsions from Copaifera spp. oleoresin that is potentially useful because of the several advantages mentioned earlier, such as its low cost and avoidance of heating and solvent use.

In control fish using only cultivation tank water, the total (100\%) mortality of A. spathulatus, N. janauachensis and M. boegeri was observed in $7 \mathrm{hr}$ of assaying at $23^{\circ} \mathrm{C}$ was reached. In another in vitro study carried out using these same monogeneans on the gills of C. macropomum, but performed at $17-18^{\circ} \mathrm{C}$, extended survival for a period of $9 \mathrm{hr}$ was observed (Soares et al., 2016). Therefore, the environmental temperature is an important factor for the survival of monogeneans during in vitro trials.

Although aquaculture is an activity of great importance in Brazil, this industry has been affected by economic losses caused by monogeneans in fish farming (Tavares-Dias \& Martins, 2017). As the main products used for treatment and control of these parasites are chemotherapeutic substances that are highly toxic to fish (Boijink et al., 2015; Soares et al., 2016), there is a need for less toxic and novel bioactive compounds (Hashimoto et al., 2016; Soares et al., 2016; Zhang et al., 2014). Phytotherapy is an alternative treatment that has shown promising antiparasitic effects against monogeneans of fish (Costa et al., 2017; Hashimoto et al., 2016; Soares et al., 2016; Zhang et al., 2014), as well as the use of nanoemulsions containing essential oils (Valentim et al., 2018).

The treatment used in the present study, with nanoemulsions prepared from C. officinalis oleoresin at 200 and $300 \mathrm{mg} / \mathrm{L}$, showed $100 \%$ efficacy against monogeneans on the gills of $C$. macropomum after $15 \mathrm{~min}$ of exposure. Similarly, $100 \mathrm{mg} / \mathrm{L}$ of C. duckei oleoresin had $100 \%$ efficacy against Anacanthorus penilabiatus and Mymarothecium viatorum of Piaractus mesopotamicus (Costa et al., 2017). After monogeneans on the gills of $C$. macropomum has been exposed to nanoemulsion of Pterodon emarginatus essential oil at $400 \mathrm{e}$ $600 \mathrm{mg} / \mathrm{L}$ for $15 \mathrm{~min}$, the anthelmintic activity rate reached $100 \%$ (Valentim et al., 2018). Monogeneans of C. macropomum exposed to Lippia alba essential oil at 1,280 and $2,560 \mathrm{mg} / \mathrm{L}$ for $20 \mathrm{~min}$ also had anthelmintic activity rate reached $100 \%$ (Soares et al., 2016). This level of efficacy against Cichlidogyrus tilapiae, Cichlidogyrus thurstonae, Cichlidogyrus halli and Scutogyrus longicornis, which are monogeneans on the gills of Oreochromis niloticus, was reached after $10 \mathrm{~min}$ of exposure to L. alba essential oil at $160 \mathrm{mg} / \mathrm{L}$ or to Mentha piperita essential oil at $320 \mathrm{mg} / \mathrm{L}$ (Hashimoto et al., 2016).

Nanoemulsion prepared from $C$. officinalis oleoresin had efficacy against monogeneans of $C$. macropomum, as well as nanoemulsion from Pt. emarginatus essential oil (Valentim et al., 2018). Thus, these 
TABLE 1 In vitro antiparasitic activity of nanoemulsion with Copaifera officinalis oleoresin against monogenean parasites on the gills of Colossoma macropomum

\begin{tabular}{|c|c|c|c|}
\hline Time & $\begin{array}{l}\text { Concentration } \\
\text { (mg/L) }\end{array}$ & Live parasites & $\begin{array}{l}\text { Dead parasites } \\
\text { (\%) }\end{array}$ \\
\hline \multirow[t]{6}{*}{$0 \mathrm{hr}$} & 0 & $18.0 \pm 3.0$ & 0 \\
\hline & 50 & $25.0 \pm 0.0$ & 0 \\
\hline & 100 & $20.3 \pm 4.2$ & 0 \\
\hline & 150 & $25.3 \pm 1.5$ & 0 \\
\hline & 200 & $23.3 \pm 2.9$ & 0 \\
\hline & 300 & $19.0 \pm 1.7$ & 0 \\
\hline \multirow[t]{6}{*}{$10 \min$} & 0 & $18.0 \pm 3.0$ & 0 \\
\hline & 50 & $25.0 \pm 0.0$ & 0 \\
\hline & 100 & $15.0 \pm 5.3$ & 26.2 \\
\hline & 150 & $18.3 \pm 6.4$ & 27.6 \\
\hline & 200 & $4.0 \pm 3.5$ & 82.9 \\
\hline & 300 & $0.7 \pm 1.2$ & 96.5 \\
\hline \multirow[t]{6}{*}{$15 \min$} & 0 & $18.0 \pm 3.0$ & 0 \\
\hline & 50 & $25.0 \pm 0.0$ & 0 \\
\hline & 100 & $11.3 \pm 5.5$ & 44.3 \\
\hline & 150 & $15.7 \pm 8.4$ & 38.2 \\
\hline & 200 & $0.0 \pm 0.0$ & 100 \\
\hline & 300 & $0.0 \pm 0.0$ & 100 \\
\hline \multirow[t]{6}{*}{$40 \min$} & 0 & $18.0 \pm 3.0$ & 0 \\
\hline & 50 & $19.0 \pm 1.0$ & 24.0 \\
\hline & 100 & $6.0 \pm 3.6$ & 70.5 \\
\hline & 150 & $0.7 \pm 1.2$ & 97.4 \\
\hline & 200 & $0.0 \pm 0.0$ & 100 \\
\hline & 300 & $0.0 \pm 0.0$ & 100 \\
\hline \multirow[t]{6}{*}{$70 \min$} & 0 & $17.7 \pm 3.1$ & 1.9 \\
\hline & 50 & $4.7 \pm 0.6$ & 81.3 \\
\hline & 100 & $0.0 \pm 0.0$ & 100 \\
\hline & 150 & $0.0 \pm 0.0$ & 100 \\
\hline & 200 & $0.0 \pm 0.0$ & 100 \\
\hline & 300 & $0.0 \pm 0.0$ & 100 \\
\hline \multirow[t]{6}{*}{$90 \mathrm{~min}$} & 0 & $17.7 \pm 3.1$ & 1.9 \\
\hline & 50 & $0.0 \pm 0.0$ & 100 \\
\hline & 100 & $0.0 \pm 0.0$ & 100 \\
\hline & 150 & $0.0 \pm 0.0$ & 100 \\
\hline & 200 & $0.0 \pm 0.0$ & 100 \\
\hline & 300 & $0.0 \pm 0.0$ & 100 \\
\hline \multirow[t]{6}{*}{$2 \mathrm{hr}$} & 0 & $17.7 \pm 3.1$ & 1.9 \\
\hline & 50 & $0.0 \pm 0.0$ & 100 \\
\hline & 100 & $0.0 \pm 0.0$ & 100 \\
\hline & 150 & $0.0 \pm 0.0$ & 100 \\
\hline & 200 & $0.0 \pm 0.0$ & 100 \\
\hline & 300 & $0.0 \pm 0.0$ & 100 \\
\hline
\end{tabular}

TABLE 1 (Continued)

\begin{tabular}{|cccc}
\hline Time & $\begin{array}{l}\text { Concentration } \\
(\mathrm{mg} / \mathrm{L})\end{array}$ & Live parasites & $\begin{array}{l}\text { Dead parasites } \\
(\%)\end{array}$ \\
\hline $5 \mathrm{hr}$ & 0 & $6.0 \pm 1.0$ & 66.7 \\
& 50 & $0.0 \pm 0.0$ & 100 \\
& 100 & $0.0 \pm 0.0$ & 100 \\
& 150 & $0.0 \pm 0.0$ & 100 \\
& 200 & $0.0 \pm 0.0$ & 100 \\
& 300 & $0.0 \pm 0.0$ & 100 \\
\hline $\mathrm{hr}$ & 0 & $0.0 \pm 0.0$ & 100 \\
& 50 & $0.0 \pm 0.0$ & 100 \\
& 100 & $0.0 \pm 0.0$ & 100 \\
& 150 & $0.0 \pm 0.0$ & 100 \\
& 200 & $0.0 \pm 0.0$ & 100 \\
& 300 & $0.0 \pm 0.0$ & 100 \\
\hline
\end{tabular}

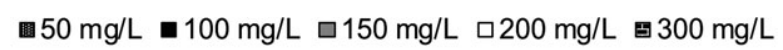

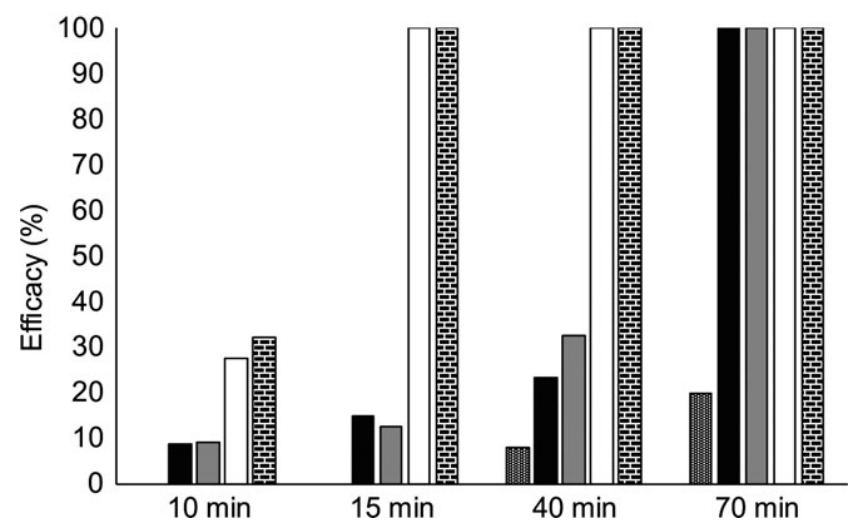

FIGURE 5 In vitro efficacy of different concentrations of nanoemulsion prepared from Copaifera officinalis oleoresin, against monogenean parasites on the gills of Colossoma macropomum

nanoemulsions have potential for use in baths of $C$. macropomum for treatment of monogenean infections. Also, these studies allowed the development of low-cost eco-friendly green natural-based nanoformulations with potential antihelmintic, using a nanobiotechnology approach. Similarly, nanoemulsion prepared from neem Azadirachta indica oil was an effective alternative for treating bacterial infection induced by Aeromonas salmonicida in catfish Clarias batrachus (Thomas et al., 2013). Furthermore, nanoemulsion prepared from $C$. officinalis oleoresin proved to be safe for adult bees (Vaucher et al., 2015), which are important non-target organisms that are highly affected by the pesticides that have historically been used within aquaculture. Therefore, the use of nanoemulsions from natural products as alternative to synthetic chemotherapeutics remains an open field for research in aquaculture.

In summary, in the present study, a nanoemulsion containing C. officinalis oleoresin dispersed through internal phase was 
developed that presented good established. The use of natural product-based nanostructures can be considered to have great potential for use in effective novel veterinary products for aquaculture. The use of plant species bioactive products that are widely available on an integrated sustainable basis also offers particular advantage, as the natural raw materials can be obtained in large amounts. Finally, as this nanoemulsion was highly effective against monogeneans from gills C. macropomum, therapeutic baths with nanoemulsion prepared with $200-300 \mathrm{mg} /$ $L$ of $C$. officinalis oleoresin should be tested for use in aquaculture of this Amazonian fish.

\section{ACKNOWLEDGEMENTS}

The authors thank FAPEAP (Prodetec Araguari; Procedural $\mathrm{N}^{\circ}$ 250.203.035/2013) for the financial support. This project had also financial support from Embrapa (Project Kamukaia 3). We also thank CAPES for the student scholarship awarded to the first author and CNPQ for the research fellowship granted to Dr. Marcos Tavares Dias (\# 303013/2015-0).

\section{ETHICAL DISCLOSURES}

This study was developed in accordance with the principles adopted by the Brazilian College of Animal Experimentation (COBEA), and authorization from Ethics Committee in the Use of Animal of the Embrapa Amapá (\# 004 CEUA/CPAFAP) was carried out.

\section{ORCID}

M Tavares-Dias (iD http://orcid.org/0000-0002-8376-1846

\section{REFERENCES}

Araújo-Lima, C., \& Goulding, M. (1998). Os frutos do tambaqui: Ecologia, conservação e cultivo na Amazônia. Tefé, Brasília: Sociedade Civil Mamirauá

Bajerski, L., Michels, L. R., Colomé, L. M., Bender, E. A., Freddo, R. J., Bruxel, F., \& Haas, S. E. (2016). The use of Brazilian vegetable oils in nanoemulsions: An update on preparation and biological applications. Brazilian Journal of Pharmaceutical Sciences, 52, 347-363. https://doi. org/10.1590/s1984-82502016000300001

Benetton, M. L. F. N., \& Malta, J. C. O. (1999). Morfologia dos estágios de náuplios e copepodito I de Perulernaea gamitanae Thatcher and Paredes, 1985 (Crustacea: Cyclopoida: Lernaeidae), parasita do tambaqui Colossoma macropomum (Cuvier, 1818), (Osteichthyes: Chracidae), cultivado em laboratório. Acta Amazonica, 29, 97-121. https://d oi.org/10.1590/1809-43921999291121

Boijink, C. L., Miranda, W. S. C., Chagas, E. C., Dairiki, J. K., \& Inoue, L. A. K. A. (2015). Anthelmintic activity of eugenol in tambaquis with monogenean gill infection. Aquaculture, 438, 138-140. https://doi. org/10.1016/j.aquaculture.2015.01.014

Cascon, V., \& Gilbert, B. (2000). Characterization of the chemical composition of oleoresins of Copaifera guianensis Desf., Copaifera duckei Dwyer and Copaifera multijuga Hayne. Phytochemistry, 55, 773-778. https://doi.org/10.1016/S0031-9422(00)00284-3
Cheong, J. N., Tan, C. P., Man, Y. B. C., \& Misran, M. (2008). a-Tocopherol nanodispersions: Preparation, characterization and stability evaluation. Journal of Food Engineering, 89, 204-209. https://doi.org/ 10.1016/j.jfoodeng.2008.04.018

Costa, J. C., Valladão, G. M. R., Pala, G., Gallani, S. U., Kotzent, S., Crotti, A. E. M., ... Pilarski, F. (2017). Copaifera duckei oleoresin as a novel alternative for treatment of monogenean infections in pacu Piaractus mesopotamicus. Aquacuture, 471, 72-79. https://doi.org/10.1016/j.a quaculture.2016.11.041

Dias, D. O., Colombo, M., Kelmann, R. G., Kaiser, S., Lucca, L. G., Teixeira, H. F., ... Koester, L. S. (2014). Optimization of copaiba oil-based nanoemulsions obtained by different preparation methods. Industrial Crops and Products, 59, 154-162. https://doi.org/10.1016/j.indcrop. 2014.05.007

Dias, D. O., Colombo, M., Kelmann, R. G., Souza, T. P., Bassani, V. L., Teixeira, H. F., ... Koester, L. S. (2012). Optimization of headspace solid-phase microextraction for analysis of $\beta$-caryophyllene in a nanoemulsion dosage form prepared with copaiba (Copaifera multijuga Hayne) oil. Analytica Chimica Acta, 721, 79-84. https://doi.org/10. 1016/j.aca.2012.01.055

Eiras, J. C., Takemoto, R. M., \& Pavanelli, G. C. (2006). Métodos de estudo e técnicas laboratoriais em parasitologia de peixes. Maringá, Brazil: Eduem.

Godoi, M. M. I. M., Engracia, V., Lizama, M. L. A. P., \& Takemoto, R. M. (2012). Parasite-host relationship between the tambaqui (Colossoma macropomum Cuvier 1818) and ectoparasites, collected from fish farms in the city of Rolim de Moura, State of Rondônia, western Amazon, Brazil. Acta Amazonica, 42, 515-524. https://doi.org/10. 1590/S0044-59672012000400009

Gomes, L. D. C., Chagas, E. C., Martins-Junior, H., Roubach, R., Ono, E. A., \& Lourenço, J. N. P. (2006). Cage culture of tambaqui (Colossoma macropomum) in a central Amazon floodplain lake. Aquaculture, 253, 374-384. https://doi.org/10.1016/j.aquaculture.2005.08.020

Hashimoto, G. S. O., Neto, F. M., Ruiz, M. L., Acchile, M., Chagas, E. C., Chaves, F. C. M., \& Martins, M. L. (2016). Essential oils of Lippia sidoides and Mentha piperita against monogenean parasites and their influence on the hematology of Nile tilapia. Aquaculture, 450, 182186. https://doi.org/10.1016/j.aquaculture.2015.07.029

Heurtault, B., Saulnier, P., Pech, B., Proust, J. E., \& Benoit, J. P. (2003). Physico-chemical stability of colloidal lipid particles. Biomaterials, 24, 4283-4300. https://doi.org/10.1016/S0142-9612(03)00331-4

IBGE. (2016). Quantidade e valor dos produtos de origem animal e variação anual [WWW Document]. IBGE - Pesqui. Pecuária Munic. Retrieved from ftp://ftp.ibge.gov.br/Producao_Pecuaria/Producao_da_Pecuaria_ Municipal/2014/xls/tab 02_brasil.zip (acessed in 10/29/2017).

Irache, J. M., Esparza, I., Gamazo, C., Agüeros, M., \& Socorro Espuelas, S. (2011). Nanomedicine: Novel approaches in human and veterinary therapeutics. Veterinary Parasitology, 180, 47-71. https://doi.org/10. 1016/j.vetpar.2011.05.028

Leong, W. F., Lai, O. M., Long, K., Man, Y. B. C., Misran, M., \& Tan, C. P. (2011). Preparation and characterisation of water-soluble phytosterol nanodispersions. Food Chemistry, 129, 77-83. https://doi.org/10. 1016/j.foodchem.2011.04.027

Lima, C. S., Medeiros, B. J. L., Favacho, H. A. S., Santos, K. C., Oliveira, B. R., Taglialegna, J. C., ... Carvalho, J. C. T. (2011). Pre-clinical validation of a vaginal cream containing copaiba oil (reproductive toxicology study). Phytomedicine, 18, 1013-1123. https://doi.org/10.1016/ j.phymed.2011.05.004

Lucca, L. G., Matos, S. P., Borille, B. T., Dias, D. O., Teixeira, H. F., Veiga, V. F. Jr, ... Koester, L. S. (2015). Determination of _ $\beta$-caryophyllene skin permeation/retention from crude copaiba oil (Copaifera multijuga Hayne) and respective oil-based nanoemulsion using a novel HS-GC/ MS method. Journal of Pharmaceutical and Biomedical Analysis, 104, 144-148. https://doi.org/10.1016/j.jpba.2014.11.013 
Ostertag, F., Weiss, J., \& McClements, D. J. (2012). Low-energy formation of edible nanoemulsions : Factors influencing droplet size produced by emulsion phase inversion. Journal of Colloid and Interface Science, 388, 95-102. https://doi.org/10.1016/j.jcis.2012.07.089

Pandey, G. (2014). Some medicinal plants to treat fish ectoparasitic infections. International Journal of Pharmaceutical \& Research Sciences, 2, 532-538.

Rodrigues, E. C. R., Ferreira, A. M., Vilhena, J. C. E., Almeida, F. B., Cruz, R. A. S., Florentino, A. C., ... Fernandes, C. P. (2014). Development of a larvicidal nanoemulsion with Copaiba (Copaifera duckei) oleoresin. Revista Brasileira de Farmacognosia, 24, 699-705. https://doi.org/10. 1016/j.bjp.2014.10.013

Simões, C. A. C. G., Conde, N. C. O., Venâncio, G. N., Milério, P. S. L. L., Bandeira, M. F. C. L., \& Veiga-Júnior, V. F. (2016). Antibacterial activity of copaiba oil gel on dental biofilm. The Open Dentistry Journal, 10, 188-195. https://doi.org/10.2174/1874210601610010188

Soares, B. V., Neves, L. R., Olveira, M. S. B., Chaves, F. C. M., Dias, M. K. R., Chagas, E. C., \& Tavares-Dias, M. (2016). Antiparasitic activity of the essential oil of Lippia alba on ectoparasites of Colossoma macropomum (tambaqui) and its physiological and histopathological effects. Aquaculture, 452, 107-114. https://doi.org/10.1016/j.aquaculture. 2015.10.029

Solans, C., Izquierdo, P., Nolla, J., \& Azemar, N. (2005). Nano-emulsions. Current Opinion in Colloid \& Interface Science, 10, 102-110. https://d oi.org/10.1016/j.cocis.2005.06.004

Solè, I., Solans, C., Maestro, A., González, C., \& Gutiérrez, J. M. (2012). Study of nano-emulsion formation by dilution of microemulsions. Journal of Colloid and Interface Science, 376, 133-139. https://doi.org/ 10.1016/j.jcis.2012.02.063

Tappin, M. R. R., Pereira, J. F. G., Lima, L. A., Siani, A. C., Mazzei, J. L., \& Ramos, M. F. S. (2004). Análise química quantitativa para a padronização do óleo de copaíba por cromatografia em fase gasosa de alta resolução. Quimica Nova, 27, 236-240. https://doi.org/10. 1590/S0100-40422004000200012

Tavares-Dias, M., \& Martins, M. L. (2017). An overall estimation of losses caused by diseases in the Brazilian fish farms. Journal of Parasitic Diseases, 41, 913-918. https://doi.org/10.1007/s12639-017-0938-y

Thatcher, V. E. (2006). Amazon fish parasites, 2nd ed. Moscow, Russia: Pensoft Publishers.
Thomas, J., Jerobin, J., Seelan, T. S. J., Thanigaivel, S., Vijayakumar, S., Mukherjee, A., \& Chandrasekar, N. (2013). Studies on pathogenicity of Aeromonas salmonicida in catfish Clarias batrachus and control measures by neem nanoemulsion. Aquaculture, 396-399, 71-75. https://doi.org/10.1016/j.aquaculture.2013.02.024

Valentim, D. S. S., Duarte, J. L., Oliveira, A. E. M. F. M., Cruz, R. A. S., Carvalho, J. C. T., Conceição, E. C., \& Tavares-Dias, M. (2018). Nanoemulsion from essential oil of Pterodon emarginatus (Fabaceae) shows in vitro efficacy against monogeneans of Colossoma macropomum (Pisces: Serrasalmidae). Journal of Fish Diseases, 41, 443-449. https://doi.org/10.1111/jfd.12739

Valladão, G. M. R., Gallani, S. U., \& Pilarski, F. (2016). South American fish for continental aquaculture. Reviews in Aquaculture, 1, 1-19.

Vaucher, R. A., Giongo, J. L., Bolzan, L. P., Côrrea, M. S., Fausto, V. P., Alves, C. F. S., ... Santos, R. C. V. (2015). Antimicrobial activity of nanostructured Amazonian oils against Paenibacillus species and their toxicity on larvae and adult worker bees. Journal of Asia-Pacific Entomology, 18, 205-210. https://doi.org/10.1016/j.aspen.2015.01.004

Veiga-Junior, V. F., Zunino, L., Patitucci, M. L., Pinto, A. C., \& Calixto, J. B. (2006). The inhibition of paw oedema formation caused by the oil of Copaifera multijuga Hayne and its fractions. Journal of Pharmacy and Pharmacology, 58, 1405-1410. https://doi.org/10.1111/j.20427158.2006.tb01659.x

Zhang, X. P., Li, W. X., Al, T. S., Zou, H., Wu, S. G., \& Wang, G. T. (2014). The efficacy of four common anthelmintic drugs and traditional Chinese medicinal plant extracts to control Dactylogyrus vastator (Monogenea). Aquaculture, 420-421, 302-307. https://doi.org/10.1016/j.a quaculture.2013.09.022

How to cite this article: Valentim DSS, Duarte JL, Oliveira AEMFM, et al. Effects of a nanoemulsion with Copaifera officinalis oleoresin against monogenean parasites of Colossoma macropomum: A Neotropical Serrasalmidae. J Fish Dis. 2018;41:1041-1048. https://doi.org/10.1111/jfd.12793 